Editors' Note: Kuhlenbaeumer critiques the study by Wu et al. on a rare FUS gene variant and essential tremor $(E T)$, pointing out its weaknesses and stressing the need for replication of the results before assuming any definite conclusion. As a result of this WriteClick exchange, the editors are establishing a policy that studies reporting a novel mutation as the cause of a neurologic disease must include an adequately powered verification sample. Should propofol be avoided in patients with mitochondrial disorder? Parness and Savard et al. explain their opposite views. Chafic Karam, MD, and Robert C. Griggs, MD

\section{IDENTIFICATION OF A NOVEL RISK VARIANT IN THE FUS GENE IN ESSENTIAL TREMOR}

Gregor Kuhlenbaeumer, Kiel, Germany: Wu et al. ${ }^{1}$ described the association between a novel rare variant in the FUS gene (Met392Ile) and ET. They claimed that they observed "a consistent trend" and a " 2 times increased risk" in the replication sample based on the finding that $2 / 250$ patients - yet only $1 / 250$ controls - showed the allele in question. The $p$ value in the replication sample is 1.0 and the $95 \%$ confidence interval of the odds ratio 0.18 to 22.29 . This is a negative and not a positive finding in the replication sample and the interpretation by the authors is misleading. The conclusion that the joint analysis of both samples is positive is also of limited importance because the number of controls in the first sample is 24 times larger than in the replication sample. Therefore, the whole association rests on 6/347 patients carrying the associated allele in the first sample. Replication is needed before considering this variant as a risk variant for ET.

Author Response: Eng-King Tan, Singapore; Yih-Ru Wu, Taipei, Taiwan: We thank Dr. Kuhlenbaeumer for his interest in our study. The frequency of the FUS variant was twice that in cases compared to controls in the second case control set. We agree that due to the rarity of the variant, the second sample set was inadequate to verify the result in our much larger discovery set. As we mentioned, further replication in different populations will be of interest.

C 2014 American Academy of Neurology
1. Wu YR, Foo JN, Tan LCS, et al. Identification of a novel risk variant in the FUS gene in essential tremor. Neurology 2013;81:541-544.

\section{PROPOFOL-RELATED INFUSION SYNDROME HERALDING A MITOCHONDRIAL DISEASE: CASE REPORT}

Jerome Parness, Pittsburgh: Savard et al. ${ }^{1}$ described a case of propofol-infusion syndrome (PRIS) heralding an occult case of mitochondrial disease. The authors stated: "Our observations support the recommendation to avoid using propofol in patients with known mitochondrial diseases.” Au contraire!

In the practice of pediatric anesthesia, propofol $(2-3 \mathrm{mg} / \mathrm{kg})$ is primarily used as a single-dose induction agent, and sometimes in an infusion for surgical cases lasting a few hours. Recent reviews of anesthetic outcomes of patients with mitochondrial disorders did not reveal adverse anesthetic outcomes. ${ }^{2,3}$ This is remarkable since many of the modern anesthetic agents — parenteral or inhaled — adversely affect mitochondrial function. ${ }^{4}$

Since all cases of PRIS result from prolonged (i.e., days) use of high-dose propofol infusion, it seems unlikely that this syndrome is due to a classic drugreceptor second-messenger interaction. Something must accumulate: the parent drug, a metabolite, a component of the lipid carrier, or some combination of the above. Propofol can affect the mitochondrion by at least 4 different mechanisms, ${ }^{4}$ yet it is remarkably safe when used in a bolus, with or without a short infusion.

Categorically banning propofol in such a heterogeneous group of patients ${ }^{5}$ is unwarranted.

Author Response: Martin Savard, Alexis F. Turgeon, Quebec City, Canada: We thank Dr. Parness for his interest and commentary. PRIS is an uncommon but potentially catastrophic clinical syndrome and no therapeutic alternatives exist aside from the withdrawal of the drug and supportive care. Our limited knowledge on the etiology and pathophysiology of PRIS preclude effectively preventing its occurrence. High doses and long-term infusion are the main risk factors. However, even with the same risk factors, some individuals experience PRIS while others do 
not, which suggests the possibility of additional unknown risk factors.

In our report, ${ }^{1}$ the patient experienced PRIS and was diagnosed with concomitant mitochondrial disease. Even though the use of propofol may seem reassuring in the setting of general anesthesia in patients with mitochondrial disease, ${ }^{2,3}$ most of these patients were exposed to a single bolus of the drug. It is still unclear how propofol may have affected the mitochondrion in the case we described but it is unlikely to be a coincidence. The safety profile of propofol in the presence of mitochondrial disease should be reconsidered, and a diagnosis of mitochondrial disease should be suspected in the context of PRIS.

(C) 2014 American Academy of Neurology
1. Savard M, Dupre N, Turgeon AF, Desbiens R, Langevin S, Brunet D. Propofol-related infusion syndrome heralding a mitochondrial disease: case report. Neurology 2013;81; 770-771.

2. Gurrieri C, Kivela JE, Bojanic K, et al. Anesthetic considerations in mitochondrial encephalomyopathy, lactic acidosis, and stroke-like episodes syndrome: a case series. Can J Anaesth 2011;58:751-763.

3. Footitt EJ, Sinha MD, Raiman JA, Dhawan A, Moganasundram S, Champion MP. Mitochondrial disorders and general anaesthesia: a case series and review. $\mathrm{Br} \mathrm{J}$ Anaesth 2008;100:436-441.

4. Niezgoda J, Morgan PG. Anesthetic considerations in patients with mitochondrial defects. Paediatr Anaesth 2013; 23:785-793.

5. Dimauro S, Schon EA, Carelli V, Hirano M. The clinical maze of mitochondrial neurology. Nat Rev Neurol 2013;9: 429-444.

\section{CORRECTION}

Correction: Copy number variants are frequent in genetic generalized epilepsy with intellectual disability

In the correction "Correction: Copy number variants are frequent in genetic generalized epilepsy with intellectual disability" (Neurology ${ }^{\circledR}$ 2013;81:2148), one name of the authors noted as inadvertently omitted from the original article's byline was misspelled. The author names should have been spelled Holger Trucks, PhD, Dennis Lal, MSc, and Thomas Sander, MD. The Neurology ${ }^{\circledR}$ editorial office regrets the error. 


\section{Neurology}

Propofol-related infusion syndrome heralding a mitochondrial disease: Case report Jerome Parness, Martin Savard and Alexis F. Turgeon

Neurology 2014;82;461-462

DOI 10.1212/01.wnl.0000443933.18269.20

\section{This information is current as of February 3, 2014}

Updated Information \& Services

References

Permissions \& Licensing

Reprints including high resolution figures, can be found at: http://n.neurology.org/content/82/5/461.2.full

This article cites 5 articles, 1 of which you can access for free at: http://n.neurology.org/content/82/5/461.2.full\#ref-list-1

Information about reproducing this article in parts (figures,tables) or in its entirety can be found online at:

http://www.neurology.org/about/about_the_journal\#permissions

Information about ordering reprints can be found online:

http://n.neurology.org/subscribers/advertise

Neurology ${ }^{\circledR}$ is the official journal of the American Academy of Neurology. Published continuously since 1951, it is now a weekly with 48 issues per year. Copyright (O 2014 American Academy of Neurology. All rights reserved. Print ISSN: 0028-3878. Online ISSN: 1526-632X.

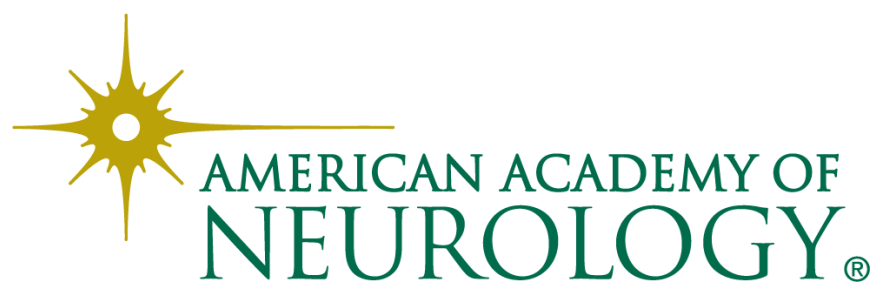

